\title{
Hydrochemical characterisation of a major central European heat flux anomaly: the Bürchau geothermal spring system, Southern Black Forest, Germany
}

\author{
Julian Rolker ${ }^{1,2^{*}}$, Eva Schill ${ }^{3}$, Ingrid Stober ${ }^{1}$, Jochen Schneider ${ }^{4}$, Thomas Neumann ${ }^{5}$ and Thomas Kohl ${ }^{1}$
}

\footnotetext{
* Correspondence: rolker@solites.de ${ }^{1}$ Geothermal Research Group, Institute of Applied Geosciences, Karlsruhe Institute of Technology, Adenauerring 20b, 76131 Karlsruhe, Germany

${ }^{2}$ Present address: Solites, Steinbeis Research Institute for Solar and Sustainable Thermal Energy Systems, Meitnerstraße 8, 70563 Stuttgart, Germany

Full list of author information is available at the end of the article
}

\begin{abstract}
Background: The possible signature of deep fluids originating from processes occurring during infiltration or circulation in a remote valley in the Black Forest (Germany), a typical infiltration area in the crystalline basement which represents a possible recharge zone of one of the major heat flux density anomalies in central Europe, has been hydrochemically characterised. Chemical and isotopic compositions of two warm springs and several cold springs in Bürchau as well as water from the Badenweiler Spa were sampled three times during June and October 2013.

Methods: A number of 70 water samples were taken at natural outlet conditions and analysed for major and trace elements, water $\mathrm{H} / \mathrm{O}$-isotope ratios and sulphur isotope ratios of dissolved sulfate. A chlorofluorocarbon (CFC) analysis was conducted to determine the underground residence time of the thermal water. To assess water-rock interactions seven rock samples representing the occurring lithological units of the study area were prepared to thin sections for polarization microscopic analysis.

Results: The main spring in Bürchau discharging water with a temperature up to $\mathrm{T}=18.1^{\circ} \mathrm{C}$ at flow rates of approximately $0.2 \mathrm{~L} \mathrm{~s}^{-1}$ is $\mathrm{Na}-\mathrm{Ca}-\mathrm{HCO}_{3}$-dominated and generally low mineralised (total dissolved solids (TDS) of about $150 \mathrm{mg} \mathrm{L}^{-1}$ ). Even lower mineralisation and temperature of a nearby spring indicates further dilution with shallow groundwater. With respect to cold springs in the vicinity, the thermal water in Bürchau is slightly enriched in $\mathrm{Cl}, \mathrm{B}, \mathrm{Li}, \mathrm{Rb}$ and $\mathrm{Cs}$. In nearby granites, sericitisation of plagioclase and oxidation of pyrite to goethite have been identified. The stable isotope composition of $\mathrm{H}$ and $\mathrm{O}$ suggests meteoric origin of the water. Chlorofluorocarbon (CFC) analyses indicate that 30\% to 40\% of the thermal water in Bürchau is younger than 60 to 70 years. Reservoir temperatures have been estimated to $40^{\circ} \mathrm{C}$ to $80^{\circ} \mathrm{C}$ using sulphate and quartz geothermometers.

Conclusions: Thus, the circulation time of the other $60 \%$ to $70 \%$ of the thermal water is longer than 70 years. Estimated reservoir temperatures in a range of $40^{\circ} \mathrm{C}$ to $80^{\circ} \mathrm{C}$ correspond to an infiltration depth of about 1,600 to 1,800 m.
\end{abstract}

\section{严 Springer}

(c) 2015 Rolker et al.; licensee Springer. This is an Open Access article distributed under the terms of the Creative Commons Attribution License (http://creativecommons.org/licenses/by/4.0), which permits unrestricted use, distribution, and reproduction in any medium, provided the original work is properly credited. 


\section{Background}

Very low-temperature and natural subsurface flow systems have been observed worldwide, especially in mountain ranges such as the Alps, the Himalayas and the Black Forest (e.g. Sonney 2010, Bucher et al. 2009). These systems are often characterised by water of meteoric origin that percolates in the uppermost crust along permeable structures (Baietto et al. 2005). It can reach elevated temperatures and considerable total dissolved solids (TDS) through water-rock interaction (e.g. Evans et al. 2005). Subsurface circulation in such settings is mainly driven by pressure differences due to the topography (Tóth 1978). Ascent paths are generally controlled by faults and fracture zones, i.e. by zones of enhanced permeability (Guglielmetti et al. 2013, Giersch 2006).

Central Europe hosts a number of important heat flux anomalies that are linked to upwelling fluids of enhanced temperature in a specific geological and tectonic setting. Major anomalies are located in the central Upper Rhine Graben to the east of the Black Forest (e.g. Baillieux et al. 2013) and to the south of the Black Forest at the High Rhine (Medici and Rybach 1995; Figure 1). They are thoroughly investigated and reach a heat flux density up to $150 \mathrm{~mW} \mathrm{~m}{ }^{-2}$. Differences in ${ }^{3} \mathrm{H}$ - and ${ }^{14} \mathrm{C}$-contents for the $\mathrm{Ca}-\mathrm{Na}$ $\mathrm{HCO}_{3}$-type water in the springs at Bürchau and Rothaus compared to the $\mathrm{Na}^{-} \mathrm{SO}_{4}$ $\mathrm{HCO}_{3}$-Cl-type in Northern Switzerland led to the interpretation that fluids in the crystalline basement of Northern Switzerland were recharged in the Black Forest (Pearson et al. 1991).

The basement rock in this area can be characterised by a heat flow pattern between the elevated temperatures at the Rhine Graben and the anomaly in Northern Switzerland (Kohl et al. 2003). Since there are no data from deep wells near Bürchau, the temperature field is only accessible through indirect observations such as hydrochemistry. The warm spring at Bürchau was first documented with a flow rate of $0.2 \mathrm{~L} \mathrm{~s}^{-1}$ and a TDS of $100 \mathrm{mg} \mathrm{L}^{-1}$ in the early 1920s (Badisches Geologisches Landesamt 1930). Extensive hydrochemical and isotopic investigations were carried out at this source by Schmassmann et al. (1984) to examine its regional relation to water from deep wells in Northern Switzerland. They concluded that the Bürchau water is probably a mixture of older crystalline water with recent water. Isotopic investigation indicated a rather local catchment area (Pearson et al. 1991). The residence time of the water is estimated to be over 25 to 30 years. However, the likely mixing leads to high uncertainty of the flow model.

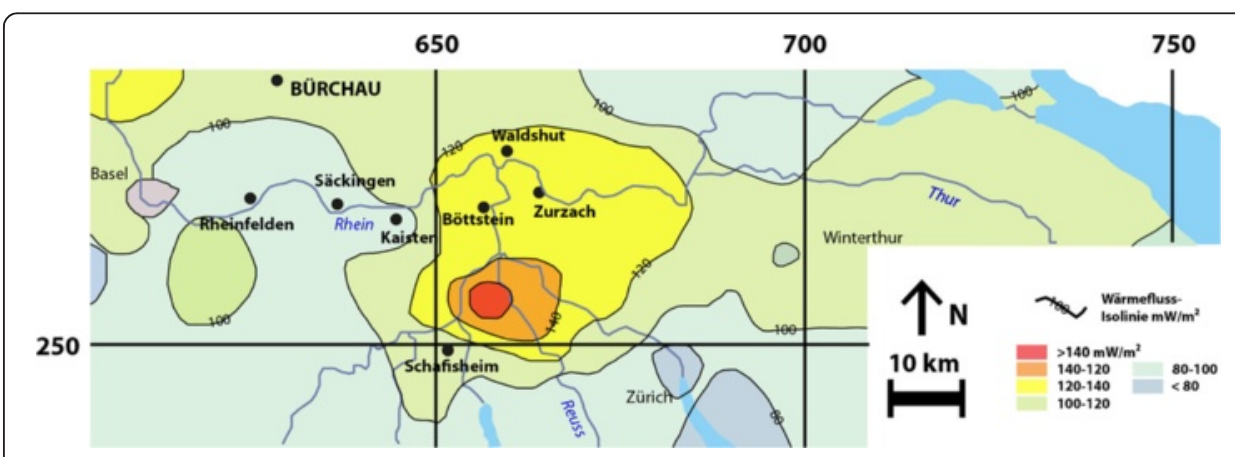

Figure 1 Heat flux map along the High Rhine River with the location of boreholes later used for comparison. Modified after Medici and Rybach 1995 and Schärli and Rybach 2002, Swiss coordinates CH93. 
In this respect, this study aims on characterising hydrothermal processes occurring in the infiltration zone of this large scale heat flux density anomaly.

\section{Study area}

The study area includes a large part of the Kleines Wiesental, a high-situated valley in the Southern Black Forest, SW-Germany. The Black Forest represents an erosional window into the Variscan crystalline basement that consists in its central part predominantly of ortho- and paragneisses (Geyer and Gwinner 2011). The boundary between the Central Black Forest Gneiss Complex to the north and the Southern Black Forest Granite and Gneiss Complex to the south is located about $2 \mathrm{~km}$ north of Bürchau (Figure 2). Both complexes are considered to be part of the Moldanubian zone of the Central-European Variscan orogen. They are separated by the Badenweiler-Lenzkirch Zone, presumably a suture zone, consisting of Ordovician to lower Carboniferous sediments and volcanic rocks as well as successions of metamorphosed volcano sediments (Sawatzki and Hann 2003). South of the Badenweiler-Lenzkirch Zone, gneisses are characterised by extensive intrusions of granitoids (Kalt et al. 2000, Figure 2).

The warm springs are located at Bürchau (628 m above sea level (a.s.l.)), about $25 \mathrm{~km}$ south of Freiburg i.Br. (Figure 2). The topography of this region is dominated by Mt. Belchen $(1,414 \mathrm{~m})$ north of Bürchau, Mt. Honeck (1,022 m) in the east and Mt. Köhlgarten (1,224 m) in the northwest. There are two discharges of warm water in Bürchau. The main discharge $\mathrm{B} 1$ is located within the river and reveals a temperature of $15^{\circ} \mathrm{C}$ to $18^{\circ} \mathrm{C}$. Its flow rate has dropped after construction work to about $0.16 \mathrm{~L} \mathrm{~s}^{-1}$. A second discharge $\mathrm{B} 2$ with a

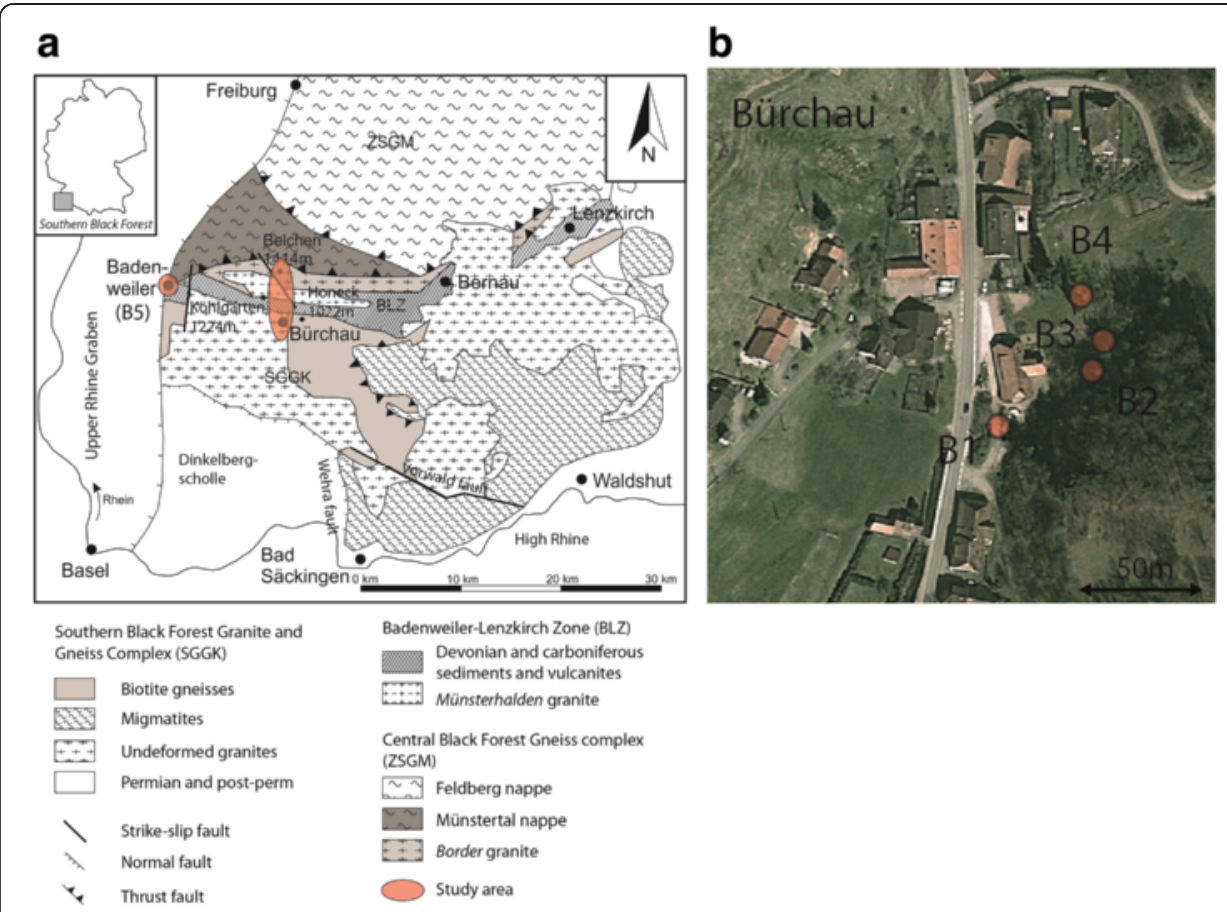

Figure 2 Area of investigation in the southern Black Forest. (a) Geological map of the southern Black Forest (modified after Sawatzki and Hann 2003) with location of the study area and Badenweiler Spa (B5). (b) Sample locations of two warm springs and one cold spring in Bürchau (B1/2 and B3, respectively) as well as a river in Bürchau (B4) (Source: Google earth). 
temperature around $9.5^{\circ} \mathrm{C}$ occurs at the rim of the riverbed 50 m northeast of B1 (Figure $2 \mathrm{~b}$ ). The thermal image of the slope at $\mathrm{B} 2$ (Figure 3) reveals a surface temperature of up to $7^{\circ} \mathrm{C}$ in contrast to the ambient temperature of $-6^{\circ} \mathrm{C}$ in October 2011 , when the picture was taken (Figure 3). In Badenweiler, west of Bürchau, another thermal spring (B5) was investigated for comparison. Its water is of meteoric origin (Berg and Genser 1961) and reveals a lower mineralisation in contrast to other thermal waters in similar tectonic settings close to the eastern boundary fault of the Upper Rhine Graben in Baden-Baden or Ohlsbach (Stober and Bucher 2000). The host rock of the springs is the Southern Black Forest Granite and Gneiss Complex occurring at the lithological contact between the biotite gneisses to the east and the un-deformed granites to the west (Figure $2 \mathrm{a}$ ).

Regional fault systems reveal mainly Hercynian and Rhenian strike directions with the ESE-WNW striking Vorwald fault and the N-S striking normal fault system of Wehr, respectively (Figure 2). All geological units are cut by granite porphyry dykes with late Visean intrusion ages (Schaltegger 2000). The orientation of a number of these dikes is in agreement with the ESE-WNW striking fault zones. The Vorwald fault, approximately 20-km long, is assumed to be a pathway for hydrothermal circulation from the area of investigation to the area of high heat flux density in Northern Switzerland (Medici and Rybach 1995, Figure 1). The origin of the fault is assumed to be pre-Variscian (Wirth 1984). The likely hydrothermal circulation along the fault zone may be indicated by the present stress field. Recent displacement is observed at the Kandern fault, a prolongation of the Vorwald fault, e.g. by the Schopfheim earthquake on 5 May 2009 with a magnitude of $M_{\mathrm{L}}=4.5$ with an epicentre located about $5 \mathrm{~km}$ to the SW of Bürchau (Bundesanstalt für Geowissenschaften und Rohstoffe BGR 2009). A regional strike-slip stress regime that was determined for the study area using inversion of focal mechanism (Kastrup et al. 2004) is consistent with the recent Schopfheim earthquake. The maximum horizontal stress $\left(\mathrm{SH}_{\max }\right)$ is oriented sub-horizontally in approximately NW-SE direction, while the minimum horizontal stress $\left(\mathrm{Sh}_{\min }\right)$ is orientated approximately NE-SW (Müller et al. 2003). Towards Northern Switzerland in the area of high heat flux density, the orientation of the stress field in the granitic basement is consistent with the one observed around Bürchau; the type of stress, however, changes into strike-slip/normal faulting regime (Kastrup et al. 2004).

\section{Methods}

For chemical characterisation of the circulation system in Bürchau, water samples were taken at natural outlet conditions. In total, seven rock samples were cut and prepared
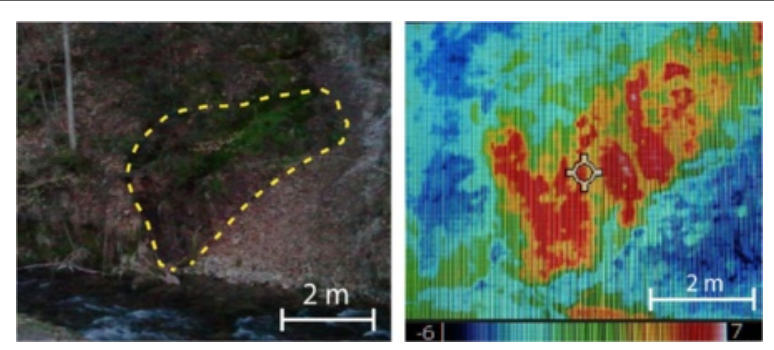

Figure 3 Warm spring B2 at the riverside in Bürchau (view from the W) and related thermography (11 September 2011). Permission: H. Senn. 
to $30-\mu \mathrm{m}$-thin sections for polarisation microscopic analysis. The fresh rock samples representing the occurring lithological units of the Southern Black Forest Granite and Gneiss Complex and the Badenweiler-Lenzkirch zone were taken in a radius of $<5 \mathrm{~km}$ from the spring B1. One additional sample was taken from the slightly altered rock sample of the Mambach granite in the fracture at B1 (Figure 4) where discharge occurs. A number of 70 water samples were taken during three field campaigns in 2013 at two warm springs (B1/2), a cold spring (B3) and the river water (B4) at Bürchau, as well as at the thermal spring near Badenweiler (B5). A seasonal monitoring of the springs was not conducted, since steady chemical composition of the fluid is indicated over decades by comparison with earlier measurements (Carlé 1975; Schmassmann et al. 1984). In order to investigate a possible effect of near surface inflow, the concentrations of major and trace elements, water $\mathrm{H} / \mathrm{O}$-isotope ratios and sulphur isotope ratios of dissolved sulphate, were determined for samples of the first two campaigns. In this respect campaign I was conducted after a period of 3 days of heavy rainfall with a total precipitation of $>100 \mathrm{~L} \mathrm{~m}^{-2}$. Campaign II was carried out after a period of 10 days without precipitation. Although temperature appears different between the JUN13 and JUL13 sampling, no significant difference in the chemical composition of the spring waters between campaigns I and II for B1 has been observed (Table 1). Campaign III for chlorofluorocarbon (CFC) analyses was conducted at B1 after a period of low precipitation ( $<50 \mathrm{~L} \mathrm{~m}^{-2}$ over 10 days). This observation is underlined by comparison with earlier measurements (Schmassmann et al. 1984; Carlé 1975) showing that the water chemistry is distributed homogenous (especially for trace elements) over decades.

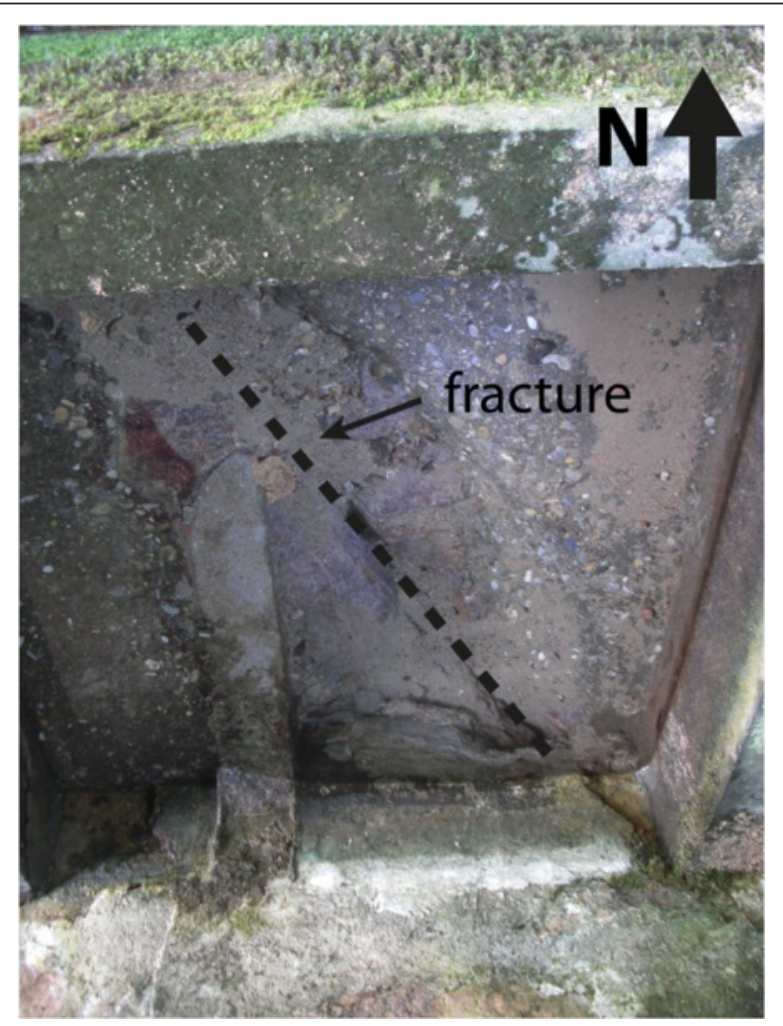

Figure 4 Warm water, tapped spring B1 in Bürchau. The strike of the fracture along which water is ascending is highlighted by the dashed line. 
Table 1 Chemical composition and stable isotope contents of waters in the study area (Bürchau, B1-4, Badenweiler, B5): results for the two sampling campaigns in June and July 2013 and earlier studies

\begin{tabular}{|c|c|c|c|c|c|c|c|c|c|c|c|c|}
\hline \multirow[t]{2}{*}{ Spring } & \multicolumn{2}{|l|}{ B1 } & \multicolumn{2}{|l|}{ B2 } & \multicolumn{2}{|l|}{ B3 } & \multicolumn{2}{|l|}{ B4 } & \multicolumn{2}{|l|}{ B5 } & \multirow{2}{*}{$\begin{array}{l}\text { B1 Schmassmann et al. (1984) } \\
1981 \text { to } 1983\end{array}$} & \multirow{2}{*}{$\begin{array}{l}\text { B1 Carlé (1975) } \\
1958\end{array}$} \\
\hline & JUN13 & JUL13 & JUN13 & JUL13 & JUN13 & JUL13 & JUN13 & JUL13 & JUN13 & JUL13 & & \\
\hline Temperature $\left[{ }^{\circ} \mathrm{C}\right]$ & 15.1 & 18.1 & 9.3 & 9.7 & - & - & 8.3 & - & 18.7 & 20.4 & 16.8 & - \\
\hline Conductivity $\left[\mu \mathrm{S} \mathrm{cm}^{-1}\right]$ & 152 & 149 & 49 & 61 & 49 & 46 & 46 & 55 & 429 & 420 & - & - \\
\hline $\mathrm{O}_{2}$ concentration [\%] & 62 & 66 & 92,8 & 77 & 105 & 97 & 98 & 90 & 72 & 71 & - & - \\
\hline Redox potential [mV] & 221 & 245 & 294 & 270 & - & 290 & 242 & 237 & 227 & 252 & - & - \\
\hline $\mathrm{pH}$ & 7.45 & 7.5 & 6.7 & 6.8 & 7.2 & 6.3 & 7.4 & 7.2 & 7.6 & 7.7 & 8.06 & 6.8 \\
\hline$\delta^{18} \mathrm{O}[\% 0]$ & -9.77 & -10.25 & -9.82 & -10.1 & - & -10.6 & - & -10.12 & -9.58 & -10.1 & -9.86 & - \\
\hline$\delta^{2} H[\% 0]$ & -68.1 & -68.7 & -68.9 & -68.4 & - & -70.9 & - & -68.0 & -67.4 & -69.2 & -69.5 & - \\
\hline$\delta^{34} \mathrm{~S}[\% 0]$ (from $\mathrm{BaSO}_{4}$ precipitation) & 5.11 & 5.00 & - & 4.12 & - & - & - & - & 12.88 & 12.95 & - & - \\
\hline$\delta^{18} \mathrm{O}[\%]$ (from $\mathrm{BaSO}_{4}$ precipitation) & 3.72 & 3.61 & - & 3.17 & - & - & - & - & 6.04 & 5.88 & - & - \\
\hline \multicolumn{13}{|l|}{ Amount $\left[\mathrm{mg} \mathrm{L}^{-1}\right]$} \\
\hline $\mathrm{Na}$ & 15.0 & 15.4 & 2.88 & 2.88 & - & 2.14 & - & 3.66 & 31.4 & 33.3 & 14.9 & 11.7 \\
\hline K & 1.21 & 1.21 & 0.55 & 0.54 & - & 0.33 & - & 0.6 & 3.1 & 3.27 & 1.21 & - \\
\hline $\mathrm{Ca}$ & 14.6 & 15.3 & 4.55 & 6.88 & - & 5.37 & - & 5.72 & 46.9 & 54.8 & 33.3 & 12.6 \\
\hline $\mathrm{Mg}$ & 1.21 & 1.3 & 0.85 & 1.33 & - & 1.11 & - & 0.84 & 6.58 & 7.16 & 2.80 & 3.7 \\
\hline $\mathrm{Li}$ & 0.0405 & 0.0419 & 0.0009 & 0.0011 & - & 0.0006 & - & 0.0007 & 0.134 & 0.138 & 0.048 & - \\
\hline $\mathrm{Sr}$ & 0.155 & 0.181 & 0.028 & 0.042 & - & 0.042 & - & 0.03 & 0.455 & 0.487 & 0.298 & - \\
\hline $\mathrm{Cl}$ & 1.85 & 1.79 & 3.3 & 3.59 & - & 1.48 & - & 3.73 & 8.58 & 8.93 & 1.91 & 4.5 \\
\hline $\mathrm{HCO}_{3}$ & 85.4 & 79.3 & 18.3 & 24.4 & - & 42.7 & - & 42.7 & 159 & 165 & 71.0 & 67.1 \\
\hline $\mathrm{SO}_{4}$ & 12.0 & 12.1 & 2.89 & 3.32 & - & 2.36 & - & 2.99 & 67.9 & 67.8 & 23.8 & 12.3 \\
\hline $\mathrm{F}$ & 1.85 & 1.9 & 0.13 & 0.23 & - & 0.2 & - & 0.12 & 0.82 & 0.8 & 1.86 & - \\
\hline $\mathrm{SiO}_{2}$ & - & 22.3 & - & 4.1 & - & 4.4 & - & 5.3 & - & 19.6 & 23.8 & 7.5 \\
\hline
\end{tabular}


Table 1 Chemical composition and stable isotope contents of waters in the study area (Bürchau, B1-4, Badenweiler, B5): results for the two sampling campaigns in June and July 2013 and earlier studies (Continued)

\begin{tabular}{|c|c|c|c|c|c|c|c|c|c|c|c|c|}
\hline \multicolumn{13}{|c|}{$\overline{\text { Amount }\left[\mu \mathrm{g} \mathrm{L}^{-1}\right]}$} \\
\hline B & 14.2 & 13.6 & 2.73 & 2.68 & - & 2.61 & - & 2.74 & 162.9 & 164 & - & - \\
\hline $\mathrm{Fe}$ & 1.32 & 2.32 & 2.51 & 1.59 & - & 1.78 & - & 10.7 & 2.03 & 2.39 & - & - \\
\hline $\mathrm{Cu}$ & 0.17 & 0.27 & 0.15 & 0.14 & - & 0.17 & - & 0.37 & 3.09 & 3.58 & - & - \\
\hline $\mathrm{Zn}$ & 1.03 & 1.9 & 1.59 & 2.37 & - & 1.88 & - & 1.85 & 98.6 & 96.4 & - & - \\
\hline As & 62.3 & 64.2 & 4.97 & 5.2 & - & 1.91 & - & 4.8 & 101.5 & 104 & - & - \\
\hline $\mathrm{Rb}$ & 6.67 & 8.12 & 2.29 & 2.67 & - & 1.74 & - & 2.29 & 15.6 & 17.1 & - & - \\
\hline Mo & 1.66 & 1.65 & 0.05 & 0.1 & - & 0.05 & - & 0.08 & 1.34 & 1.33 & - & - \\
\hline Cs & 2.65 & 3.92 & 0.7 & 0.82 & - & 0.54 & - & 0.38 & 14.29 & 15.1 & - & - \\
\hline U & 6.51 & 7.1 & 0.09 & 0.14 & - & 0.03 & - & 0.12 & 5.59 & 5.79 & - & - \\
\hline $\mathrm{Ba}$ & 156 & 187 & 254 & 333 & - & 199 & - & 75.6 & 56.7 & 59.5 & - & - \\
\hline $\operatorname{TDS}\left[\mathrm{mg} \mathrm{L}^{-1}\right]$ & 135 & 153 & 35.6 & 49.8 & - & 61.7 & - & 67.8 & 328 & 365 & - & - \\
\hline
\end{tabular}


During the field campaigns, physic-chemical parameters of the springs, including temperature, $\mathrm{pH}$, oxygen concentration, redox potential and electrical conductivity, were measured in situ using a WTW Multiline P4 (WTW Wissenschaftlich-Technische Werkstätten GmbH, 82362 Weilheim, Germany). Additionally, the alkalinity was determined by titration with an alkalinity field set (Aquamerck, Merck KGaA, 64293 Darmstadt, Germany) immediately after sampling.

Water samples were collected in new 60-, 100- and 1,000-mL polyethene (PE) bottles. Before collecting water samples, all materials were well flushed with the water that was to be sampled later. Samples for the anion and cation analytics were filtered with a $0.45-\mu \mathrm{m}$ membrane filter. To prevent the formation of metal hydroxide complexes, samples for the major and trace elements were acidified with sub-boiled nitric acid $\left(\mathrm{HNO}_{3}\right)$ to $\mathrm{pH}<2$ immediately after sampling. Samples for anion analytics $\left(\mathrm{SO}_{4}, \mathrm{~F}, \mathrm{Cl}\right)$ were darkened with aluminium foil and frozen until the day of analysis. Water samples for CFC measurements were collected from the outflow B1 in 1-L faceted glass bottles locked in water-filled gas-tight brass tubes. The empty glass bottle is plunged completely in a metallic tin. The water is filled in the glass bottle using a rubber tube positioned at its bottom. The sampling is carried out in a 10-L plastic bucket. After complete overflow of the bottle and the tin and continuous flushing for at least several minutes to remove atmospheric air from the sample bottle, the tube was pulled out and the bottle was closed under water in the tin. The tin was closed with a sealing rubber ring to avoid exchange with air.

Different analytical methods like the atomic absorption spectroscopy (ASS), the atomic emission spectroscopy (AES), the ion chromatography (IC) and the inductivecoupled-plasma mass spectroscopy (ICP-MS) had been successfully applied for analysing geothermal waters (Arnórsson et al. 2006, Armannsson and Olafsson 2007). The analyses of the acidified samples for major $(\mathrm{Na}, \mathrm{K}, \mathrm{Ca}, \mathrm{Mg})$ and trace elements $(\mathrm{Li}, \mathrm{B}$, $\mathrm{Fe}, \mathrm{Cu}, \mathrm{Zn}, \mathrm{As}, \mathrm{Rb}, \mathrm{Sr}, \mathrm{Mo}, \mathrm{Cs}, \mathrm{U}, \mathrm{Ba})$ with ICP-MS at the Institute of Mineralogy and Geochemistry IMG at KIT showed a high reproducibility. Certified reference material HPS VF 5 from High Purity Standards was used. The detection limit for major elements is $<0.01 \mathrm{mg} \mathrm{L}^{-1}$ and $<0.013 \mu \mathrm{L}^{-1}$ for trace elements except B and Fe with a detection limit of $0.56 \mu \mathrm{L}^{-1}$ and $1.41 \mu \mathrm{L}^{-1}$, respectively.

Samples for anion analytics $\left(\mathrm{SO}_{4}, \mathrm{~F}, \mathrm{Cl}\right)$ were analysed with ion chromatography at the IMG laboratory at the KIT. The coefficient of determination at the calibration for the standard solution was $99.9972 \%$ in average.

The dissolved silica content was measured by ultraviolet-visible (UV/VIS) photometer (Lambda 2, PerkinElmer, Waltham, MA, USA) and the molybdenum blue method. The basis of this method is the formation of a silica-molybdenum blue complex in the presence of ascorbic acid. The intensity of the blue coloration after adding specific solutions depends on the amount of dissolved silica. The absorption of light determined with a UV/VIS photometer can be used to quantify the amount of dissolved silica.

Water samples for H/O-isotope measurements were collected in 100-mL PE bottles. The bottles were closed under water to prevent contamination by air. The hydrogen and oxygen isotope ratios were determined with the Liquid Water Isotope Analyser (LWIA, Los Gatos Research Inc., Mountain View, CA, USA). As a calibration standard, LGR5A, LGR6A and LGR7A were used. The mean standard deviation for $\delta^{2} \mathrm{H}$ is $0.35 \%$ and for $\delta^{18} \mathrm{O} 0.09 \%$. 
Sulphur and oxygen isotope composition of dissolved sulphate was measured with an isotope-ratio mass spectrometer (IRMS) at the IMG laboratory of the KIT. Therefore, dissolved sulphate was precipitated from water samples by adding barium chloride. The precipitated barium sulphate was dried and analysed with an IRMS. The mean standard deviations are $0.03 \%$ and $0.14 \%$ for $\delta^{34} \mathrm{~S}$ and for $\delta^{18} \mathrm{O}$, respectively.

The concentration of different CFCs in groundwater, emitted during different periods since the 1930s into the air, provides a useful tracer to indicate underground residence times due to high chemical stability under aerobic conditions (Rowland and Molina 1975). Generally, low CFC concentrations in groundwater suggest a relatively long residence time of $>60$ to 70 years indicating a deep circulation system in the study area. During groundwater recharge, the CFCs are incorporated in the groundwater based on the specific gas solubility. Due to CFC input curves, the proportion of young water and ideally also the mean residence time can be distinguished (Plummer and Busenberg 1999).

CFC samples were analysed at the Spurenstofflabor Dr. Harald Oster (Wachenheim, Germany). The water samples were analysed for trichlorofluoromethane (CFC-11), CFC-12 and trichlorotrifluoroethane (CFC-113) using purge and trap gas chromatography with an electron capture detector. The measurements generally are performed by direct injection of about $20 \mathrm{~mL}$ of water to the stripping chamber. A transfer gas is used to extract the CFCs from the water sample. The reconstruction of the age of the water is based on the historic data of atmospheric CFC concentrations. The concentrations in the sample are determined by atmospheric CFC concentrations and Henry's law describing the proportionality of gas dissolution to its partial pressure. An altitude of $1,100 \mathrm{~m}$ a.s.l. with an annual mean temperature of $6^{\circ} \mathrm{C}$ was assumed according to the weather history at the study area. Furthermore, the salinity of the water samples was taken into account for the descriptions of distinct input functions for the area of recharge. These distinct input functions are integrated in a lumped parameter program using the exponential model after Malloszewski and Zuber (1992).

Resampling the Bürchau springs allows for comparing the results with former investigations and for enlarging the existing dataset. We collected water samples to measure CFC to tackle the above mentioned uncertainty due to mixing processes in a quantitative way.

With respect to the possible temperature distribution at depth, we compared different silica-geothermometers with $\mathrm{SO}_{4}^{2-}-\mathrm{H}_{2} \mathrm{O}$ geothermometers, obtained from S-isotopy.

Data from Schmassmann et al. (1984) and Carlé (1975) were included in the interpretation to determine possible changes in the hydrochemical characteristics.

\section{Results and discussion}

The analysis of the tectonic structures reveals that three to four tectonic features of different type or orientation join directly at Bürchau or a few kilometres in the north. In the direct vicinity of the spring, a number of different arms of dikes of a lateVariscian, porphyric granite join in a kind of triple junction. The major arm is oriented N-S following the valley of Kleines Wiesental and is transforming towards the north of Bürchau in a fault zone cutting through the Badenweiler-Lenzkirch zone. 
The two minor arms of the intrusion are orientated NE-SW and NW-SE. The orientation of the outflow fracture of B1 at Bürchau coincides with the latter direction (Figure 4).

\section{Hydro-geochemical characteristics}

In the following, we will discuss the results listed in Table 1. The discussion is focused on the Bürchau (B1) and Badenweiler (B5) waters since they reveal the highest total mineralisation in the area. We observe temperature differences of $1.7^{\circ} \mathrm{C}$ to $3.0^{\circ} \mathrm{C}$ between the JUN13 and JUL13 campaigns for B5 and B1, respectively. The specific electric conductivity is rather stable with 152 and $429 \mu \mathrm{S} \mathrm{cm}^{-1}$ in JUN13 and 149 and 420 $\mu \mathrm{S} \mathrm{cm} \mathrm{cm}^{-1}$ in JUL13 for B1 and B5, respectively. Redox potential is observed to increase slightly from JUN13 to JUL13 from 221 (B1) and $227 \mathrm{mV}$ (B5) to 245 (B1) and $252 \mathrm{mV}$ (B5), while the $\mathrm{pH}$ increases from $\mathrm{pH}=7.45$ (B1) and 7.6 (B5) to 7.5 (B1) and 7.7 (B5). The chemical composition of the $\mathrm{B} 1$ water of (Figure 5) is dominated by $\mathrm{Ca}, \mathrm{Na}$ and $\mathrm{HCO}_{3}$. Its mineralisation with TDS $=153 \mathrm{mg} \mathrm{L}^{-1}$ differs from the other samples $\mathrm{B} 2$ to B4 with TDS between 50 and $68 \mathrm{mg} \mathrm{L}^{-1}$, respectively, and B5 with TDS of $365 \mathrm{mg} \mathrm{L}^{-1}$. It should be mentioned that the thermal water of $\mathrm{B} 1$ is enriched in $\mathrm{Li}, \mathrm{Cl}, \mathrm{F}, \mathrm{B}, \mathrm{Rb}$ and Cs with respect to $\mathrm{B} 2$ and $\mathrm{B} 4$ (see Table 1). The enrichment of trace elements like fluorine is often documented for water from fractured granite in the Black Forest (Göb et al. 2013, Hofmann 1989). Changes in the concentration of some elements of the different sources and in particular temperature changes in B1 and B5 may indicate a possible increased influx of shallow subsurface water after rainfall in the JUN13 campaign. Most of the variation is however within the uncertainty of the measurements.

Since a link between the Bürchau waters and the High Rhine region in terms of infiltration and discharge has been postulated by Schmassmann et al. (1984) and reactivated Variscian fault zones are suspected to provide sufficient permeability for fluid transport (Schill et al.

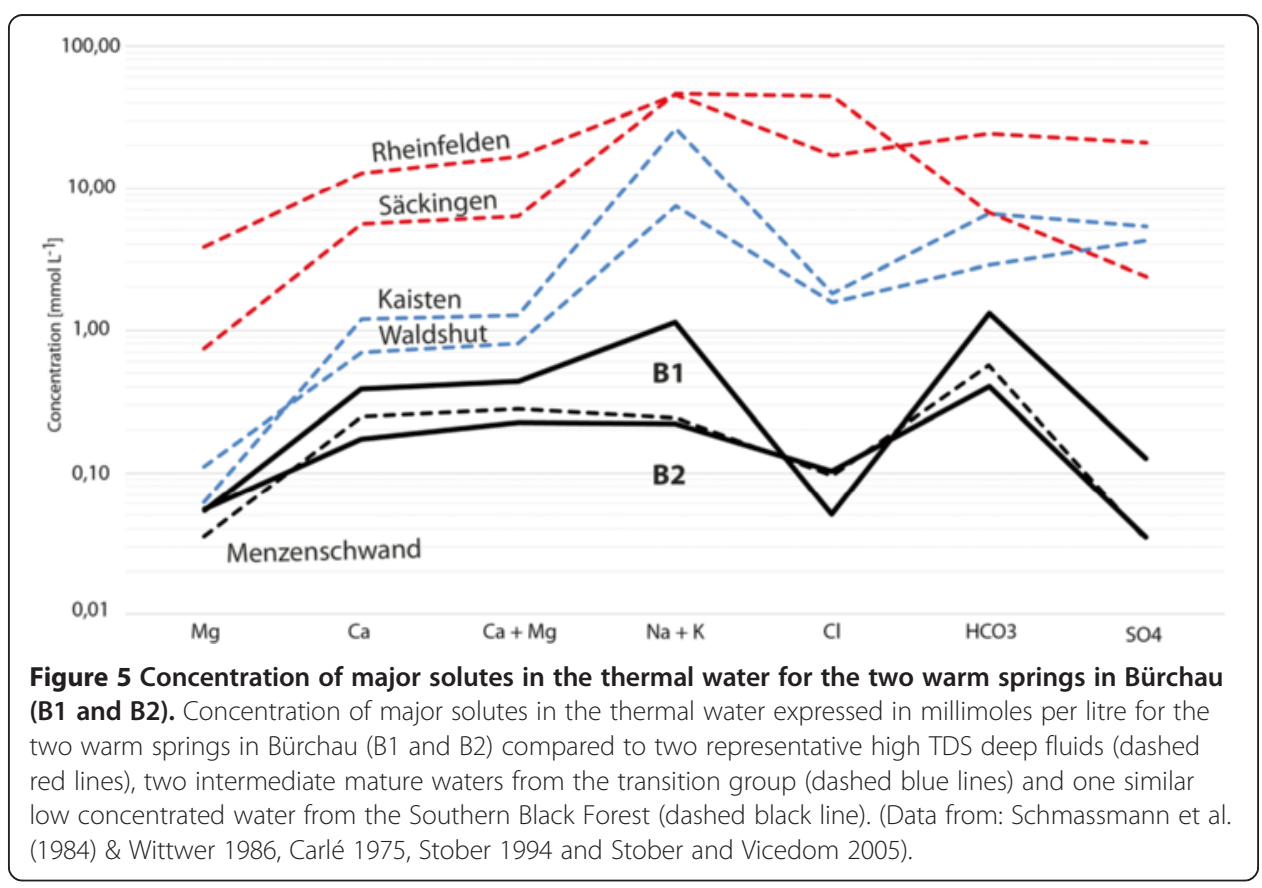


2011), we have compiled the major solutes of the waters in Figure 5. It results that the thermal water in the study area is $\mathrm{Na}-\mathrm{Ca}-\mathrm{HCO}_{3}$-dominated revealing chemical characteristics that are similar to representative crystalline basement groundwater from the Black Forest, but of lower mineralisation and a significant influence of surface water.

The relationship between $\delta^{18} \mathrm{O}$ and $\delta^{2} \mathrm{H}$ is shown in Figure 6. Since the isotope ratio follows the global meteoric water line, there is no isotopic shift due to boiling processes. The values show a difference between sampling campaign I to II. The $\delta^{18} \mathrm{O}$ values in campaign II are more negative. Most likely, this can be attributed to the heavy rainfall before sampling of campaign II. This resulted in a backshift to lighter $\delta^{18} \mathrm{O}$ values in campaign I due to significant infiltration of surface water in the direct vicinity of the source. In campaign II, water originates mainly from higher recharge areas. The decrease of $\delta^{18} \mathrm{O}$ and $\delta^{2} \mathrm{H}$ values between the Mt. Belchen and B1 to B3 and B5 can be attributed to altitude effects since there is a difference in altitude of several hundred metres between Bürchau and Mt. Belchen as well as Badenweiler and Mt. Belchen. A minimum value for the altitude of infiltration of about $870 \mathrm{~m}$ a.s.l. with an annual mean temperature of $6^{\circ} \mathrm{C}$ has been inferred using the $\delta^{18} \mathrm{O}$ to altitude ratio of Pearson et al. (1991) for the NE Jura Mountains and the Black Forest.

\section{Petrography}

Petrographic analyses of the thin sections of all granite samples from the study area (Figure 7) reveal sericitisation of plagioclase. Although the TDS between 35 to $153 \mathrm{mg} \mathrm{L}^{-1}$ at Bürchau indicates only little water-rock interaction, this sericitisation may among others represent one possible source of alteration of plagioclase in the presence of $\mathrm{CO}_{2}$ (Equation 1).

$$
\begin{aligned}
& \begin{array}{l}
\mathrm{Na}_{4} \mathrm{CaAl}_{6} \mathrm{Si}_{14} \mathrm{O}_{40} \\
\text { (plagioclase) }
\end{array}+3 \mathrm{H}_{2} \mathrm{O}+2 \mathrm{CO}_{2} \leftrightarrow \underset{\text { (kaolinite) }}{\mathrm{Al}_{2} \mathrm{Si}_{2} \mathrm{O}_{5}(\mathrm{OH})_{4}} \\
& +\underset{\text { (albite) }}{4 \mathrm{NaAlSi}_{3} \mathrm{O}_{8}+\mathrm{Ca}^{2+}}+2 \mathrm{HCO}_{3}^{-}
\end{aligned}
$$

From the isotopic composition of the Bürchau water, it should be mentioned that it is inconclusive to prove sericitisation. Furthermore, the exact composition of plagioclase was not identified in this study.

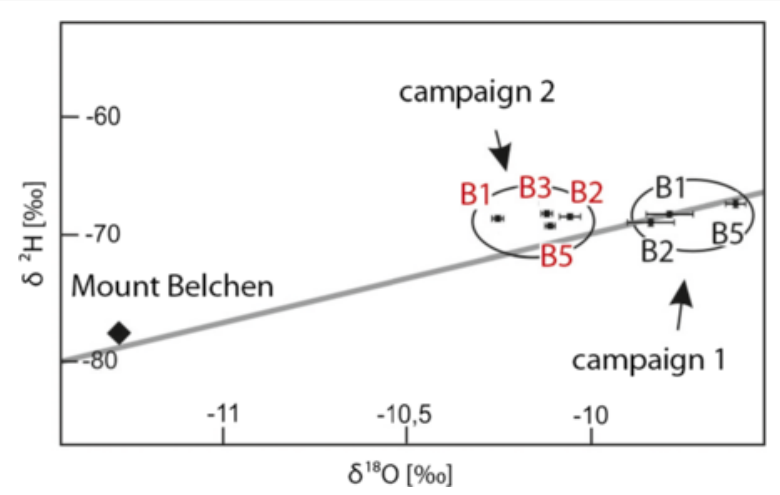

Figure $6 \delta^{2} \mathrm{H} / \delta^{18} \mathrm{O}$ isotopy of campaign 1 (black), campaign 2 (red) and Mount Belchen (black diamond). 


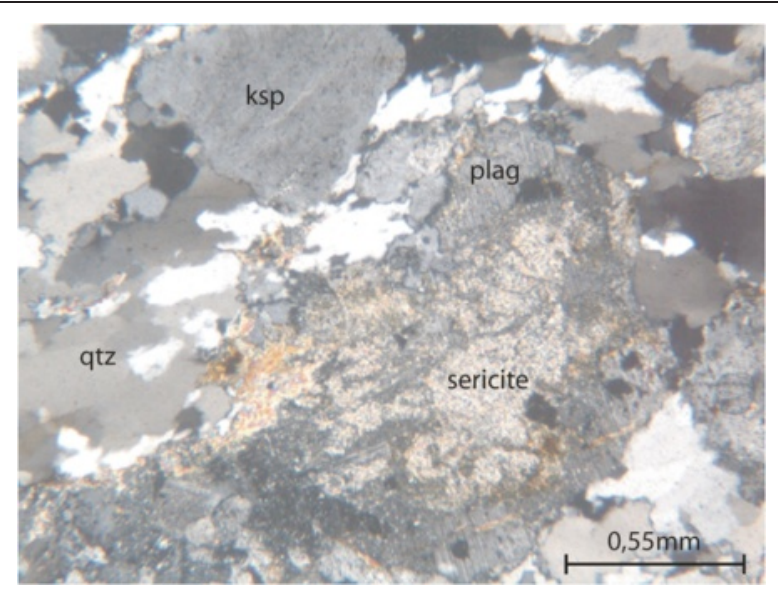

Figure 7 Representative example of the Mambach granite with sericitised plagioclase (sample taken at the discharge B1). Ksp = alkali feldspar, qtz = quartz.

Thin sections of the granite sample from B1 show distinct weathering reactions of opaque minerals to reddish secondary minerals that indicate the oxidation of pyrite to goethite (Figure 8). The oxidation of pyrite can be described with the following equation:

$$
\begin{aligned}
& 2 \mathrm{FeS}+7 \mathrm{H}_{2} \mathrm{O}+7.5 \mathrm{O}_{2} \\
& \text { (pyrite) }
\end{aligned} \underset{\begin{array}{l}
\mathrm{Fe}(\mathrm{OH})_{3}+4 \mathrm{SO}_{4}{ }^{2-}+8 \mathrm{H}^{+} \\
\text {(goethite) }
\end{array}}{ }
$$

\section{Chlorofluorocarbon analysis}

The amount of specific CFCs for B1 obtained from the sampling campaign III are listed in Table 2. Assuming a contamination of surface water as shown by the stable isotope results of campaign I and II, the infiltration altitude for the groundwater recharge is estimated iteratively using the below presented results to about $500 \mathrm{~m}$ above B1 at a mean temperature of $5^{\circ} \mathrm{C}$. For this case, specific harps were constructed using the exponential model of Malloszewski and Zuber (1992) for further interpretation. In Figure 9,

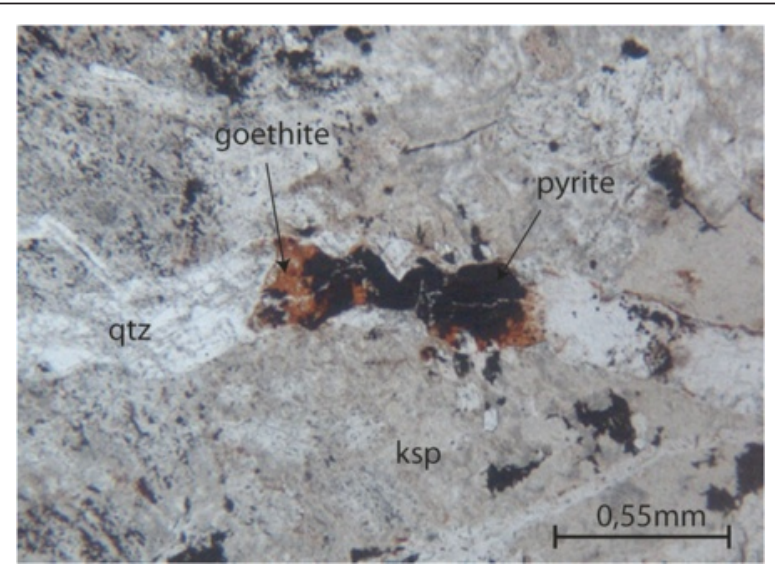

Figure 8 Pyrite oxidation in quartz (qtz) vein surrounded by alkali feldspar (ksp). 
Table 2 Amount of CFCs and standard deviation at B1 from the sampling campaign III

\begin{tabular}{|c|c|c|c|}
\hline \multirow{2}{*}{ Sample name } & \multicolumn{3}{|l|}{ Trace gases } \\
\hline & $\begin{array}{l}\text { Trichlorofluoromethane } \\
\text { (F11) }\end{array}$ & $\begin{array}{l}\text { Dichlorodifluoromethane } \\
\text { (F12) }\end{array}$ & $\begin{array}{l}\text { 1,1.2-Trichlorotrifluoroethane } \\
\text { (F113) }\end{array}$ \\
\hline & {$\left[\mathrm{pmol} \mathrm{L}{ }^{-1}\right]$} & {$\left[\mathrm{pmol} \mathrm{L}{ }^{-1}\right]$} & {$\left[\mathrm{pmol} \mathrm{L}{ }^{-1}\right]$} \\
\hline Spring B1 & \pm 0.2 & \pm 0.05 & \pm 0.05 \\
\hline
\end{tabular}

the results of the CFC analysis are represented for the specific sampling period and recharge area for CFC-113 and CFC-11. Data points at the top on the right of the harp would indicate a young water amount of $100 \%$. The results indicate a mixed ground water composition of minimum two components. The younger component appears to be younger than 60 years and has a proportion of about $30 \%$ to $40 \%$. The major groundwater component of B1 (60\% to 70\%) is older than 60 years.

\section{Geothermometers}

Geothermometers are based on temperature-dependant chemical reactions or isotope equilibrium fractionation relations from which the equilibrium temperatures can be calculated. The applicability to low-temperature reservoirs is a matter of debate, since the majority of geothermometers were developed and calibrated for high-enthalpy geothermal systems (Fournier 1977, Arnórsson 1983). To obtain higher reliability of estimated reservoir temperatures, in this study, we tested sulphate geothermometers that have recently been successfully applied for low-enthalpy systems $\left(\mathrm{T}<150^{\circ} \mathrm{C}\right)$ in

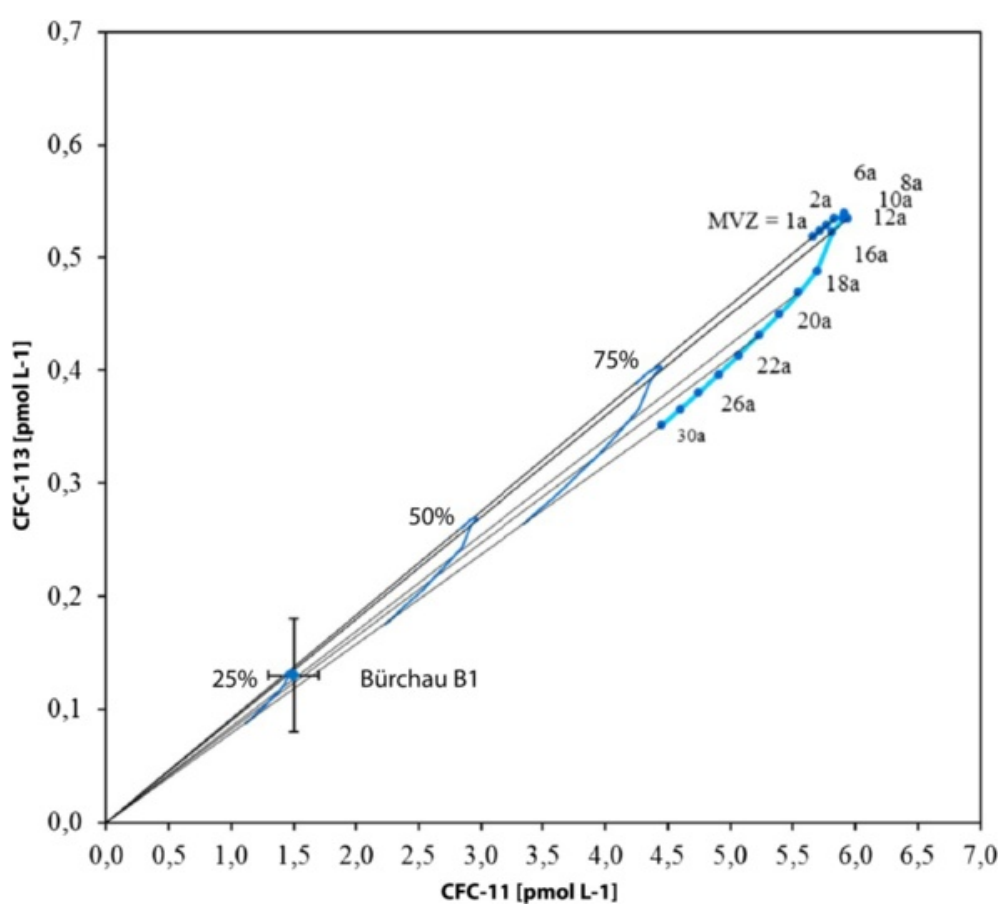

Figure 9 CFC-113 vs. CFC-11 diagram for warm spring in Bürchau (B1) for groundwater recharge area at 1,100 $\mathrm{m}$ a.s.l. 
Table 3 Calculated reservoir temperatures

\begin{tabular}{|c|c|c|c|}
\hline \multirow[t]{3}{*}{ Geothermometer } & Temperature calculation $\left[\mathrm{t}\right.$ in $\left.{ }^{\circ} \mathrm{C}\right]$ & \multirow{3}{*}{$\begin{array}{l}\text { Calculated } \\
\text { reservoir } \\
\text { temperature } \\
\text { for } \mathrm{B} 1\left[{ }^{\circ} \mathrm{C}\right]\end{array}$} & \multirow{3}{*}{$\begin{array}{l}\text { Calculated } \\
\text { reservoir } \\
\text { temperature } \\
\text { for } \mathrm{B} 5\left[^{\circ} \mathrm{C}\right]\end{array}$} \\
\hline & $\mathrm{S}=\mathrm{Si}$-concentration as $\mathrm{SiO}_{2}$ in $\mathrm{mg} \mathrm{kg}^{-1}$ & & \\
\hline & $\begin{array}{l}a=\text { isotopic relation between } \mathrm{SO}_{4} \text { and } \mathrm{H}_{2} \mathrm{O} \\
\text { (fractionation factor) }\end{array}$ & & \\
\hline Quartz (Fournier 1977) & \multirow{2}{*}{$\begin{array}{l}t=\frac{1,309}{5.19-\operatorname{logs}}-273.15 \\
t=-55.3+0.3659 S-5.3954 \times 10^{-4} S^{2} \\
+5.5132 \times 10^{-7} S^{3}+74.36 \log S\end{array}$} & 68 & 63 \\
\hline $\begin{array}{l}\text { Quartz (Arnórsson et al. } \\
\text { 1998a) }\end{array}$ & & 55 & 49 \\
\hline Quartz (Verma 2000) & $t=\frac{1,175}{4.88-\log 5}-273.15$ & 60 & 55 \\
\hline $\begin{array}{l}\text { Chalcedony (Fournier } \\
\text { 1977) }\end{array}$ & $t=\frac{1,032}{4.69-\log 5}-273.15$ & 36 & 31 \\
\hline $\begin{array}{l}\text { Chalcedony (Arnórsson } \\
\text { et al. 1983b) }\end{array}$ & $\mathrm{t}=\frac{1,112}{4.91-\log 5}-273.15$ & 39 & 34 \\
\hline $\begin{array}{l}\mathrm{SO}_{4}^{2-}-\mathrm{H}_{2} \mathrm{O} \text { (Halas and Pluta } \\
2000)\end{array}$ & $10^{3} \ln a_{(\mathrm{SO} 4-\mathrm{H} 2 \mathrm{O})}=2.41 \cdot 10^{6} / t^{2}-5.77$ & 77 & 59 \\
\hline $\mathrm{SO}_{4}^{2-}-\mathrm{H}_{2} \mathrm{O}$ (Zeebe 2010) & $10^{3} \operatorname{lna}_{(\mathrm{SO} 4-\mathrm{H} 20)}=2.68 \cdot 10^{6} / t^{2}-7.45$ & 81 & 65 \\
\hline
\end{tabular}

addition to silicate geothermometers (Boschetti 2012). A sulphate geothermometer is derived from the oxygen isotope composition of dissolved sulphate and water.

Calculated reservoir temperatures for B1 and B5 are listed in Table 3. Temperatures derived from silica geothermometers for $\mathrm{B} 1$ are in the range of $55^{\circ} \mathrm{C}$ to $68^{\circ} \mathrm{C}$ for the quartz geothermometer and slightly below $40^{\circ} \mathrm{C}$ for the chalcedony geothermometer. Within the range of up to $80^{\circ} \mathrm{C}$, the calculated reservoir temperatures derived from

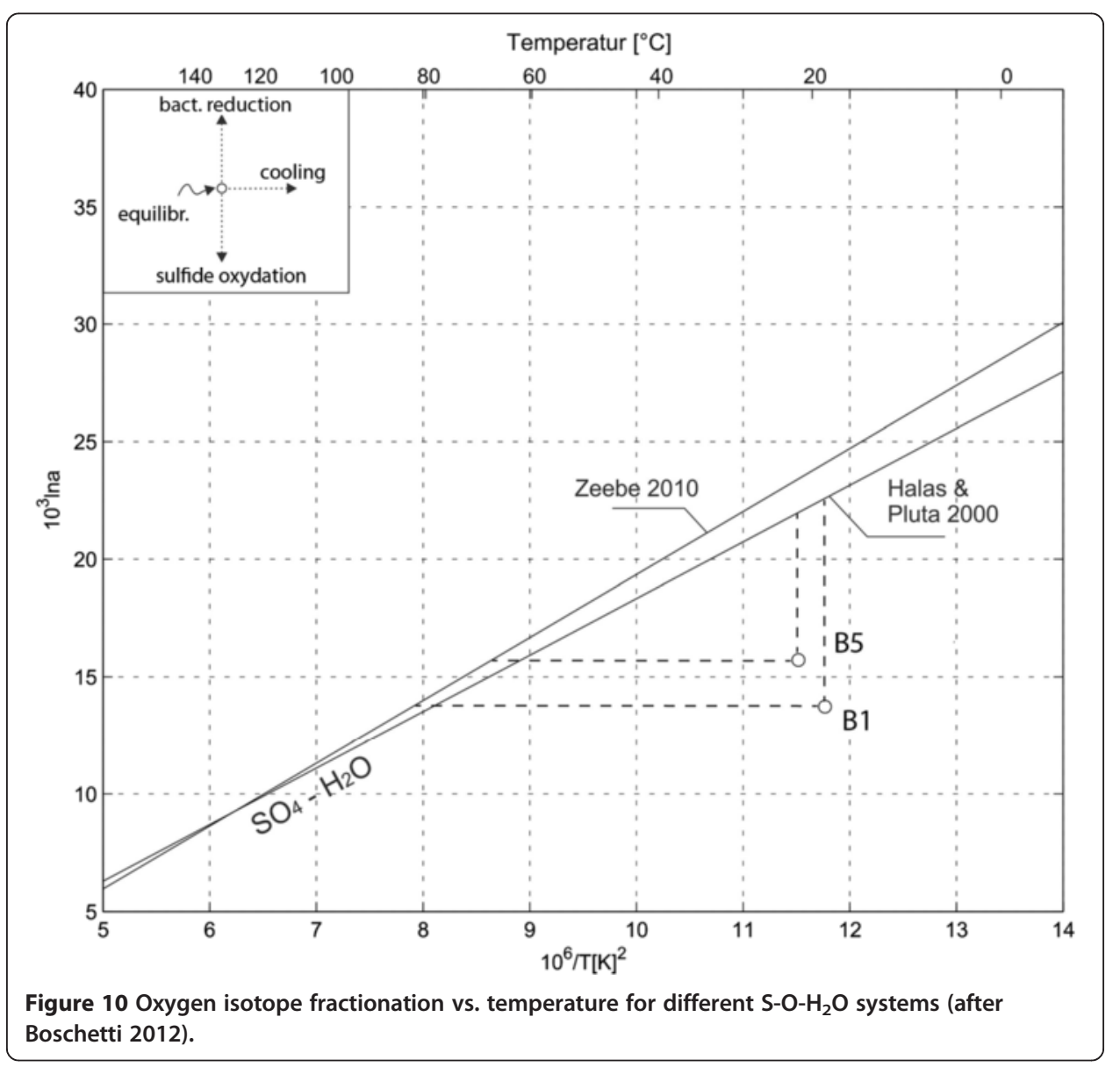


sulphate geothermometers are higher than those derived from silica geothermometers. Similar to spring B1, the calculated temperatures for the Badenweiler Spa (B5) are uniform and show reasonable results in the range of $49^{\circ} \mathrm{C}$ to $63^{\circ} \mathrm{C}$ for silicate geothermometer and $\pm 60^{\circ} \mathrm{C}$ for sulphate geothermometer. Since we observe massive sericitisation of plagioclase in thin sections, enough $\mathrm{SiO}_{2}$ in solution is assumed to form equilibrium with quartz over time.

All water samples (B1, B2 and B5) fall into the zone of immature water in the ternary $\mathrm{Na}-\mathrm{K}-\mathrm{Mg}^{1 / 2}$ diagram (Giggenbach 1988) indicating little water-rock interaction, i.e. no equilibrium condition. Reservoir temperatures for B2, B3 and B4 are not listed, since dilution with surface groundwater leads to inconsistent temperatures. This leads to the conclusion that calculated reservoir temperatures for the Bürchau side are questionable.

For evaluating the sulphate-water oxygen isotope geothermometers, the theoretical (Zeebe 2010) and empirical (Halas and Pluta 2000) isotope fractionation factors within the range of $0^{\circ} \mathrm{C}$ to $150^{\circ} \mathrm{C}$ were considered (Figure 10). Due to a very likely dilution by near surface water, $\mathrm{B} 2$ has been excluded from further analyses. Both samples, B1 and B5, are shifted from the $\mathrm{SO}_{4}^{2-}-\mathrm{H}_{2} \mathrm{O}$ equilibrium area. This shift may result from conductive cooling during the ascent of the fluid and/or from isotopic effects due to sulphide oxidation (Boschetti 2012). Since indication for oxidation of pyrite to goethite is found in the thin sections (Figure 8), the calculated reservoir temperatures with the sulphate isotope geothermometers tend to be overestimated. In this case, both conductive cooling and sulphidic oxidation influence the oxygen isotopic fractionation within the geothermal water.

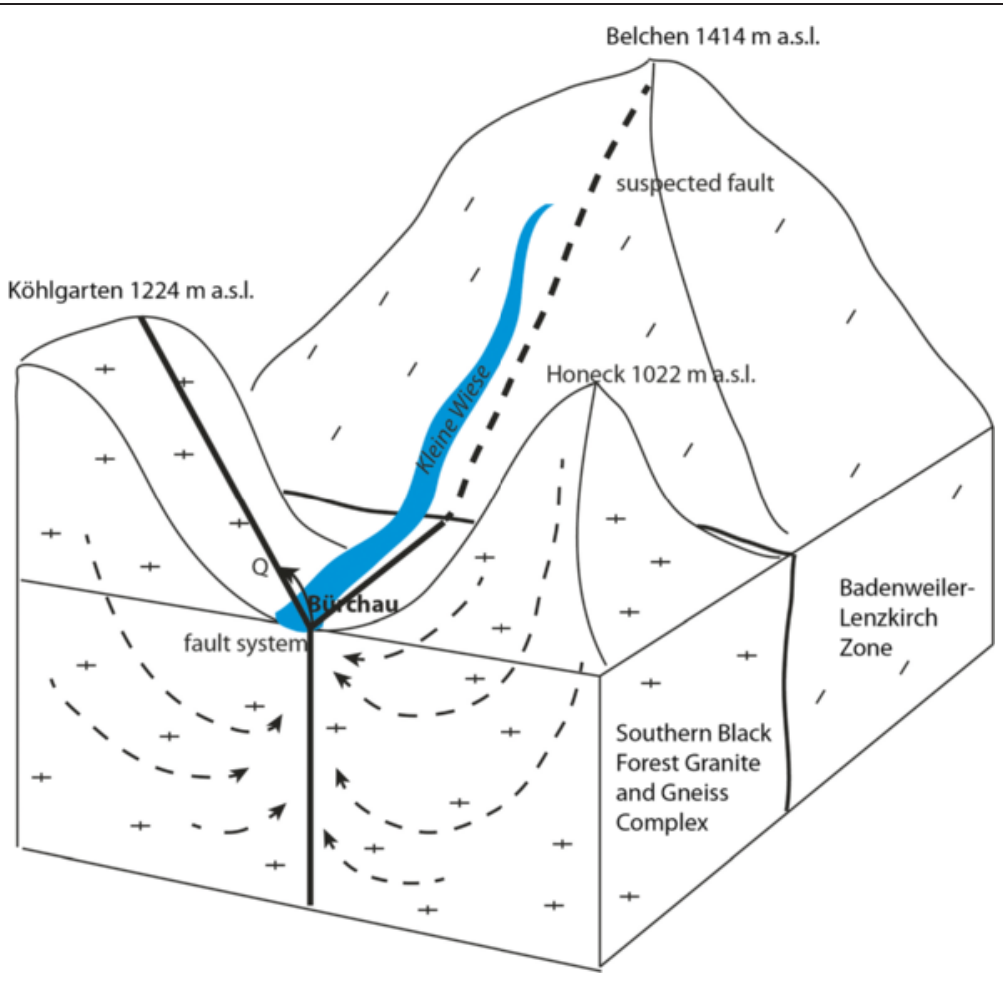

Figure 11 Conceptual model of the Bürchau flow system. 


\section{Conclusions}

The very low-temperature fluid that rises along open NW-SE discontinuities in the Mambach granite is of meteoric origin with a low mineralisation of $\mathrm{Na}-\mathrm{Ca}-\mathrm{HCO}_{3}$ type. All samples plotted in the $\delta^{18} \mathrm{O} / \delta^{2} \mathrm{H}$ diagram occur close to the meteoric water line indicating only little significant water-rock interactions. Sericitisation of plagioclase and pyrite oxidation in quartz vein is observed in thin sections. Infiltration of the water has been estimated iteratively to occur at an altitude of approximately $1,100 \mathrm{~m}$ at an annual mean temperature of $5^{\circ} \mathrm{C}$. Figure 11 shows a conceptual flow model of the Bürchau flow system. Sulphate isotope geothermometer appears to be applicable to the very low-temperature reservoirs of the Black Forest. Although possibly slightly overestimated, it provides most-consistent temperatures ranging between $77^{\circ} \mathrm{C}$ and $87^{\circ} \mathrm{C}$ for $\mathrm{B} 1$ and $59^{\circ} \mathrm{C}$ to $65^{\circ} \mathrm{C}$ for Badenweiler. CFC analyses show that $30 \%$ to $40 \%$ of the thermal water in Bürchau is younger than 60 to 70 years. Thus, the circulation time of the other $60 \%$ to $70 \%$ of the thermal water is longer than 70 years.

Finally, our results provide a reference for processes occurring already in the infiltration area of the Black Forest. A thermo-hydraulic model will be established in a forthcoming paper.

Competing interests

The authors declare that they have no competing interests.

\section{Authors' contributions}

The manuscript is based in JR's master thesis with the sampling, laboratory measurements and interpretation of the geochemical and petrological analyses. ES linked the results with the heat flux anomaly in the northern Switzerland and wrote a significant part of the manuscript. IS supervised the work on the sericitization. JS interpreted the CFC measurements. TN supervised the laboratory work. TK provided input on topography-driven systems.

\section{Acknowledgements}

We acknowledge the association Erneuerbare Energien Kleines Wiesental e.V. for financial support and the assistance during field work, especially Harald Senn. Special thanks go to Bernd Richter from the Cassiopeia Spa in Badenweiler for the opportunity of sampling the thermal water. We would also like to thank the three reviewers for their very helpful comments. This study was carried out in the framework of the HGF portfolio project 'Geoenergy'.

\section{Author details}

${ }^{1}$ Geothermal Research Group, Institute of Applied Geosciences, Karlsruhe Institute of Technology, Adenauerring 20b, 76131 Karlsruhe, Germany. ${ }^{2}$ Present address: Solites, Steinbeis Research Institute for Solar and Sustainable Thermal Energy Systems, Meitnerstraße 8, 70563 Stuttgart, Germany. ${ }^{3}$ Institute for Nuclear Waste Disposal, Karlsruhe Institute of Technology, Hermann-von-Helmholtz-Platz 1, 76128 Karlsruhe, Germany. ${ }^{4}$ Hydrosion GmbH, Tizianstr. 96, 80638 Munich, Germany. ${ }^{5}$ Institute of Mineralogy and Geochemistry, Karlsruhe Institute of Technology, Adenauerring 20b, 76131 Karlsruhe, Germany.

Received: 14 June 2014 Accepted: 3 December 2014

Published online: 17 February 2015

References

Arnórsson S, Bjarnason JÖ, Giroud N, Gunnersson I, Stefánsson A (2006) Sampling and analysis of geothermal fluids. Geofluids 6:203-216

Armannsson H, Olafsson M (2007) Geothermal Sampling and Analysi. Paper presented at Short Course II on Surface Exploration for Geothermal Resources, organized by UNU-GTP and KenGen. Lake Naivasha, Kenya

Baietto A, Cadoppi P, Martinotti G, Perello P, Vuataz F-D (2005) Mechanisms of up-rise of the hot thermal springs of Valdieri (Argentera Massif, Maritime Alps, northwestern Italy). Geophysical Research Abstracts 7:03167

Baillieux P, Schill E, Edel J-B, Mauri G (2013) Localization of temperature anomalies in the Upper Rhine Graben: insights from geophysics and neotectonic activity. International Geology Review 1-19. doi:10.1080/00206814.2013.794914.

Berg D, Genser H (1961) Geologische Voraussetzungen und hydrogeologische Deutung der Thermen von Badenweiler (SW-Schwarzwald). Jahresbericht und Mitteilungen des Oberrheinischen Geologischen Vereins 43:7-24

Bundesanstalt für Geowissenschaften und Rohstoffe BGR (2009) EISY Earthquake Informations-SYstem, BGR Hannover, Germany. http://www.bgr.bund.de/EN/Themen/Seismologie/Erdbebenauswertung_en/D_seit_1968_en/ d_1968_node.html. Accessed 17 Jul 2013

Boschetti T (2012) Oxygen isotope equilibrium in sulphate-water systems: a revision of geothermometric applications in low-enthalpy systems. Journal of Geochemical Exploration 124:92-100

Bucher K, Zhang L, Stober I (2009) A hot spring in granite of the Western Tianshan, China. Applied Geochemistry 24:402-410 
Carlé W (1975) Die Mineral- und Thermalwässer von Mitteleuropa. Geologie, Chemismus, Genese. Wissenschaftliche Verlagsgesellschaft, Stuttgart

Evans MJ, Derry LA, France-Lanord C (2005) Hydrothermal flux of metamorphic carbon dioxide from the Central Nepal Himalaya. American Geophysical Union 86:T23C-0581

Fournier RO (1977) Chemical geothermometers and mixing models for geothermal systems. Geothermics 5(1-4):41-50

Geyer OF, Gwinner MP (2011) Geologie von Baden-Württemberg, 5, 5th edn. Auflage, Schweizerbart, Stuttgart

Giersch C (2006) Thermohydraulik des kristallinen Grundgebirges am Beispiel des östlichen Oberrheingrabens. Dissertation, University of Karlsruhe

Giggenbach WF (1988) Geothermal solute equilibria. Derivation of Na-K-Mg-Ca geoindicators. Geochimica et Cosmochimica Acta 52(12):2749-2765

Göb S, Gührung JE, Bau M, Markl G (2013) Remobilization of U and REE and the formation of secondary minerals in oxidized U deposits. American Mineralogist 98:530-548

Guglielmetti L, Negro F, Mauri G, Vuataz F-D, Abdelfettah Y, Clerc N, Giroud N, Marguet L, Schill E (2013) GeoNE: an integrated project for the exploratione of low enthalpy deep aquifers in the canton of Neuchatel, western Switzerland. European Geothermal Congress, Pisa

Halas S, Pluta I (2000) Empirical Calibration of Isotope Thermometer Delta ${ }^{18} \mathrm{O}\left(\mathrm{SO}_{4}\right)$ - Delta ${ }^{18} \mathrm{O}\left(\mathrm{H}_{2} \mathrm{O}\right)$ for Low Temperature Brines. V Isotope Workshop. European Society for Isotope Research, Krakau, Poland

Hofmann B (1989) Genese, Alteration und rezentes Fliess-System der Uranlagerstätte Krunkelbach (Menzenschwand, Südschwarzwald) Dissertation, University of Bern

Kalt A, Altherr R, Hanel M (2000) The Variscan basement of the Schwarzwald. Eur J Mineral 12:1-43

Kastrup U, Zoback ML, Deichmann N, Evnas KF, Giardini D, Michael AJ (2004) Stress field variations in the Swiss Alps and the northern Alpine foreland derived from inversion of fault plane solutions. Journal of Geophysical Research, 109, doi: 10.1029/2003JB002550 B01402.

Kohl T, Andenmatten N, Rybach L (2003) Geothermal resource mapping-example from northern Switzerland. Geothermics 32(4-6):721-732

Malloszewski P, Zuber A (1992) On the calibration and validation of mathematical models for the interpration of tracer experiments in groundwater. Advances in Water Resources 15(1):47-62

Medici F, Rybach L (1995) Geothermal map of Switzerland 1:500'000 (heat flow density). Schweizerische Geophysikalische Kommission 30:36

Pearson F Jr, Balderer W, Loosli H, Lehmann BE, Matter A, Peters T, Schassmann H, Gautschi A (1991) Applied Isotope Hydrogeology, A case study in Northern Switzerland, vol 43, Studies in Environmental Science. Elsevier, Amsterdam

Plummer LN, Busenberg E (1999) Chlorofluorocarbons, chapter 15. In: Cook P, Herczeg AL (eds) Environmental Tracers in Subsurface Hydrology. Kluwer Academic Publishers, Boston, pp 441-478

Rowland FS, Molina MJ (1975) Chlorofluoromethans in the environment. In: Cook PG, Solomon DK, Plummer LN, Busenberg E, Schiff SL (eds) Chlorofluorocarbons as Tracers of Groundwater Transport Processes in a Shallow, Silty Sand Aquifer, Water Resources Research

Sawatzki G, Hann E (2003) Badenweiler-Lenzkirch-Zone (Südschwarzwald). Erläuterung mit Hinweisen für Exkursionen. Landesamt für Geologie, Rohstoffe und Bergbau Baden-Württemberg, Freiburg i. Br

Schärli U, Rybach L (2002) Bestimmung thermischer Parameter für die Dimensionierung von Erdwärmesonden; Vergleich: Erfahrungswerte - Labormessungen - Response Test. In: Eugster W, Laloui L (eds) Proceedings Workshop Geothermische Response Tests, Schweizerische Vereinigung für Geothermie SVG, Lausanne, Switzerland, 25-26 October 2001

Schaltegger U (2000) U-Pb geochronology of the Southern Black Forest Batholith (Central Variscan Belt): timing of exhumation and granite emplacement. International Journal of Earth Sciences 88:814-828

Schill E, Kohl T, Geiermann J, Baujard C, Koch S, Deckert H, Munoz G, Abdelfettah Y (2011) Multi-disciplinary prospection approach for EGS reservoirs in the German Variscian basement: PROCEEDINGS, Thirty-Sixth Workshop on Geothermal Reservoir Engineering, Stanford University, Stanford, California, SGP-TR-191

Schmassmann H, Balderer W, Kanz W, Pekdeger A (1984) Beschaffenheit der Tiefengrundwässer in der zentralen Nordschweiz und angrenzenden Gebieten. NAGRA Techn. Bericht NTB 84-21, Nagra, Wettingen

Sonney R (2010) Groundwater flow, heat and mass transport in geothermal systems of a Central Alpine Massif. The cases of Lavey-les Bains, Saint-Gervais-lesBains and Val d'Illiez. PhD thesis, University of Neuchâtel

Stober I, Bucher K (2000) The composition of groundwater in the continental crystalline crust. Hydrogeology of Crystalline Rocks, vol 34. Kluwer Academic Publishers, pp 141-176

Stober I, Vicedom R (2005) Erschließung von Thermalwasser in Waldshut-Tiengen. Berichte Naturforschende Gesellschaft Freiburg i.Br.: 95/1, 173-188

Tóth J (1978) Gravity-inducd cross-formational flow of formation fluids, red earth region, Alberta, Canada: analysis, patterns, and evolution. Water Resources Research 14:805-843

Verma M (2000) Revised Quartz Solubility Temperature Dependence Equation along the Water-Vapor Saturation Curve, Proceedings World Geothermal Congress. Kyushu-Tohoku, Japan, pp 1927-1932

Wirth G (1984) Kleintektonische Untersuchungen im Grund- und Deckgebirge des Südostschwarzwalds (Baden-Württemberg). Arb Inst Geol Paläont Univ Stuttgart 78:85-136

Wittwer C (1986) Sondierbohrungen Böttstein, Weiach, Riniken, Schafisheim, Kaisten, Leuggern. Probenahmen und chemische Analysen von Grundwässern aus den Sondierbohrungen. NAGRA Techn. Bericht NTB 84-21, Nagra, Wettingen

Zeebe RE (2010) A new value for the stable oxygen isotope fractionation between dissolved sulfate ion and water. Geochim. Cosmochim. Acta 74:818-828. doi: 10.1016/j.gca.2009.10.034

Badisches Geologisches Landesamt (1930) Die radioaktive Thermalquelle in Bürchau. Freiburg i Br 34:38

Müller B, Wehrle V, Hettel S, Sperner B, Fuchs K (2003) A new method for smoothing orientated data and its application to stress data, in Fracture and In-Situ Stress Charaterization of Hydrocarbon Reservoirs. In: Armeen MS (ed) Geological Society Special Publication, vol 209, pp 107-126

Arnórsson S (1983) Chemical equilibria in Icelandic geothermal systems - Implication for chemical geothermometry investigations. Geothermics 12(2-3):119-128 
Arnórsson S, Andresdottir A, Gunnarsson I, Stefánsson A (1998a) New calibration for the quartz and Na/K geothermometers - valid in the range $0-350^{\circ} \mathrm{C}$, Proceedings of Geoscience Society of Iceland Annual Meeting, April 1994, pp 42-43

Arnórsson S, Gunnlaugsson E, Svavarsson H (1983b) The chemistry of geothermal waters in Icelannd III. Chemical geothermometry in geothermal investigations. Geochim Cosmochim Acta 47:567-577

Stober I (1994) Ergebnisse geohydraulischer Untersuchungen im kristallinen Grundgebirge des Schwarzwaldes und seiner Randgebiete. DGM, Koblenz 38:170-178

\section{Submit your manuscript to a SpringerOpen ${ }^{\circ}$ journal and benefit from:}

- Convenient online submission

- Rigorous peer review

- Immediate publication on acceptance

- Open access: articles freely available online

- High visibility within the field

- Retaining the copyright to your article

Submit your next manuscript at $>$ springeropen.com 